\title{
La política en entredicho
}

Osvaldo lazzetta

Osvaldo lazzetta es Investigador del Consejo de Investigaciones de la Universidad Nacional de Rosario y Profesor de la Facultad de Ciencia Pollitica y RR.II. de la misma institución; Berutti 2353, (2000) Rosario. Tel: (0341) 4808521/22. Fax: (0341) 4808520.

E-mail: iazzetta@arnet.com.ar

\section{Resumen}

Aunque abundan evidencias de los límites que hoy ofrece la política para regular la economía, no hay unidad de criterio respecto a las fuentes que generan tal restricción. Existe sobre este tema una amplia literatura que da cuenta de los factores estructurales que hoy condicionan la relación entre ambos términos, pero estos rasgos universales asumen notas peculiares en el caso argentino pues -aunque no resulte privativo de nuestro país- debemos añadirle el auge de un sentido común dominante que coincide en resaltar la ineficacia de la "política" y de los "políticos» para ofrecer respuesta a las cuestiones que hoy debe atender.

El trabajo analiza algunas vertientes de la "antipolítica» vigente, $y$ explora las posibilidades para una recuperación de la regulación política jaqueada por un fuerte descrédito y factores estructurales que desafían su capacidad de coordinación.
Una versión preliminar de este trabajo fue presentada en el $5^{\circ}$ Congreso Nacional de Ciencia Pollitica, Río Cuarto, noviembre de 2001. El autor agradece los comentarios recibidos en dicho encuentro y, especialmente, las valiosas observaciones efectuadas por Guillermo O'Donnell a una versión posterior.

\section{Summary}

Although there are a lot of evidences of the limits that politics has in order to regulate economy, there isn't an only criterion about the sources that generate such restriction. On this subject, there is a wide literature about the structural factors that condition the relationship between both terms nowadays, but, these universal traits have some peculiarities in the Argentine case because we must add the boom of a dominant common sense about the politics and politician's inefficiency for solving the matters that they must attend.

This paper analyses several angles of this "antipolitics» issue and explore the possibilities of recovering the politic regulation harassed by a great disbeliever and structural factors that challenge its coordination capacity. 